\title{
Manufacturing Dissent: \\ The New Economy of Power Relations in Multicultural Teacher Education
}

\author{
Katherine Richardson Bruna \\ lowa State University \\ U. S. A.
}

This article challenges conventional understandings of White preservice teacher resistance by contextualizing it within the historically situated pedagogical

relations of the multicultural teacher education classroom. It describes the power effects of a cultural mismatch-driven, "critical" reflection approach to the preparation of the White preservice teacher and offers as an alternative a practice of Loving Subversion. In this approach, critical reflection is used not to reinscribe White racist identity but to develop a purposeful sense of White antiracism. A practice of Loving Subversion is necessary, it is argued, if we are to build genuine capacity among White preservice teachers for effective work with culturally and linguistically diverse students.

The Force of Cultural Mismatch in Multicultural Teacher Education Manufacturing Dissent: Reflection as Regulation

The Research Background (Re)Inscribing White Identity: Constructing White Resistance Putting "Education" Back in Multicultural Teacher Education Loving Subversion: Toward the Pedagogy of White Anti-Racism

Conclusion

Notes

References

I am standing puzzled, unable to decide whether the veil is really being lifted, or lowered more firmly in place; whether I am witnessing a revelation

or a more efficient blinding (Ellison, 1947, p. 36).

The conviction that truth can be discovered through the self-examination of consciousness and the confession of one's thoughts and acts now seems

so natural, so compelling, indeed so self-evident, that it seems unreasonable to posit that such self-examination is a central component in a strategy of power (from Foucault's Afterword in Dreyfus \& Rabinow, 1983, p. 175).

In this article, I use interactions between a preservice teacher, Yvonne, and her multicultural teacher educator, Ellen, to problematize three themes that have become central tropes in the multicultural teacher education literature: White identity, resistance, and reflection. Specifically, I highlight the tension between Yvonne's perception of herself as a color-blind "good White" (Scheurich, 1993; Thompson, 2003)—someone who thinks that "people are people and it doesn't matter what they look like"-and Ellen's perception of Yvonne as a colorand-power evasive (Frankenberg, 1993) "bad White." I believe Yvonne's conscious decision to "turn off" Ellen, preferring to doodle in her notebook rather than engage in dialogue over racial privilege, affords us an important opportunity 
to interrogate the purpose and practice of critical reflection in multicultural teacher education and its relationship to the resistance of White preservice teachers.

Yvonne's resistance, the multicultural teacher education literature explains, should not come as a surprise. As a "White, Anglo-Saxon, lower or middle-class female who has grown up in a suburban or rural area...is monolingual in English... and has attended a local college or university close to her home" (Mayer-Smith, Moon, \& Wideen, 1998), Yvonne is the "typical" preservice teacher (p. 140). As such, she believes that schooling is benevolent and meritocratic, whiteness is normative, and "seeing race" is necessarily prejudicial (King, 1997). In other words, as a "typical" preservice teacher, Yvonne is predisposed to resistance before the "Cultural Diversity" course even begins. Her decision to "turn off" is, after all, just evidence that Yvonne really does lack the understandings that multicultural teacher education courses are designed to provide.

I aim to challenge this chain of reasoning by proposing that an analysis of Yvonne's resistance needs to move beyond Yvonne herself and into the broader field of pedagogical relations in which, I argue, such resistance has been (mis)construed. I suggest that multicultural teacher education's obsession with the notion of "cultural mismatch" has served to label the White preservice teacher as "a particular human kind for pedagogical intervention" (Popkewitz, 2004, p. 4)—aka a "bad White"-resulting in a pedagogical practice that I describe, invoking Herman and Chomsky (1988), as "manufacturing dissent." In this cultural mismatch-driven practice in which White preservice teachers' oppositional identities are fabricated for them by the instructor and their experiences in learning about diversity are of questionable value, is the veil of perception they bring to the multicultural teacher education classroom being lifted or lowered more firmly in place?

I begin my challenge by describing how multicultural teacher education focuses on White teacher identity and how that positions the "typical" White teacher as "a particular human kind for pedagogical intervention." I refer to this knowledge production process, in which critical reflection plays a key role, as "manufacturing dissent." Multicultural teacher educators' investment in fabricating oppositional identities in their classrooms, predicated upon the identity of the "typical" White teacher as a "particular human kind," generates pedagogical relations, like those between Yvonne and Ellen that lead to experiences that Dewey termed "miseducative." These are experiences that have "the effect of arresting or distorting the growth of further experience" (1938, p. 25). Resistance, specifically such as Yvonne's decision to turn off, is evidence of such arrest and distortion. I then turn my attention specifically to the use of critical reflection in multicultural teacher education as an example of a miseducative "pedagogical intervention." I discuss how the use of critical reflection is part of a larger reflective turn in teacher professionalization that 
reflects modern economies of power (Foucault, 1983, p. 210). I finally conclude by outlining an alternative practice of Loving Subversion ${ }^{1}$. This approach permits "typical" preservice teachers to discover aspects of themselves, more particularly a purposeful sense of White anti-racism, too readily withheld by the cultural mismatch framework. A practice of Loving Subversion is necessary, I assert, if we are to build real capacity among White preservice teachers for effective work with culturally and linguistically diverse students. Right now the current conception and practice of multicultural teacher education works against this very goal.

\section{The Force of Cultural Mismatch in Multicultural Teacher Education}

Critical perspectives on multicultural education view the field's historically liberal focus "on promoting tolerance through a "conversion of individuals'" (Troyna \& Williams, 1986, as cited in Duesterberg, 1999, p. 753) as narrowminded. In singling out Whites as "flawed protagonists in their racial relations with minorities," this focus makes educational equity out to be a matter of human relations only and not of any larger historical or structural consequence (McCarthy, 1993, as cited in Duesterberg, 1999, p. 753). We see an emphasis on racial categorization and "conversion" in the discourse of cultural mismatch, more recently termed the "demographic divide" (Gay \& Howard, 2000). This discourse does two things: First, the cultural mismatch discourse points to the "gap" between the White teacher and her "Other" students of color. For example, in 2004-2005 a little more than $40 \%$ of elementary and secondary students in the U.S. were from non-dominant ethnic groups (U. S. Department of Education, 2006) while $87 \%$ of teachers were White (American Association of Colleges of Teacher Education, 1999). Second, the cultural mismatch discourse proposes that these White teachers are inherently ill-suited to teach outside of their own ethnicity. For instance, Gomez (1994) refers to cultural mismatch when she writes that the "race, social class... and language backgrounds of prospective teachers affect their attitudes toward 'Others,' their willingness to live and be part of communities with 'Others,' to teach 'Others,' and to expect that 'Others' can learn" (pp. 320-1). In this way, cultural mismatch is a discourse that aligns the White teacher with racism—-passive or not (Marx, 2006)—so that the main task of multicultural teacher education becomes that of having the White preservice teacher confront her "White racism" (Sleeter, 1994) by making meaning of her "Whiteness" (McIntyre, 1997). Notably, course objectives become framed in these terms and these statements like "The course objective is to make preservice teachers (mostly White) aware of the issues of racism, culture, power, and oppression in the United States and the role they play in the reality of these issues" (Parks, 2006, original parentheses) become so naturalized that the parenthetical emphasis on the White preservice teacher is not interrogated. The enduring assumption is that there is some essential or true inner White identity that such courses must redress. 
The fact of cultural mismatch in the United States is absolutely uncontroversial: as previously cited, $87 \%$ of public school teachers are White and experience significantly higher socio-economic outlooks than do their students of color who comprise, in some schools and districts, a majority of the student population (Choy et al, 1993; Council of Economic Advisors, 1998). The force of cultural mismatch, the effect it has in shaping approaches and pedagogical relations in multicultural teacher education, however, merits examination.

\section{Manufacturing Dissent: Reflection as Regulation}

To the extent that critical reflection is duplicitous, that is, to the extent that a multicultural teacher educator frames critical reflection as simply an exploratory process, when, in fact, he or she has a prescribed reflective product or "right answer" in mind, this educator is participating in the practice of "manufacturing dissent." In choosing this phrase, I deliberately invoke Herman \& Chomsky's (1988) "Manufacturing Consent" in which the authors expose how the mass media system purports to serve the people of the United States while it instead works at the hands of powerful government and corporate interests as a tool of public deception. I mean to make a similar case by drawing attention to the use of critical reflection with White preservice teachers. This is important since the emancipatory tone of scholars' general support for critical reflection situates it as something apart from (instead of a part of) the very power relations it is meant to critique.

One of the first to write extensively about the role of reflection in teacher education was Dewey (1938). Dewey was writing at a time in which historical changes in social organization had led to changes in social regulation requiring a "self" capable of "self"-management (Popkewitz, 1991, p. 223). In Europe, a shift had occurred in the $17^{\text {th }}-19^{\text {th }}$ centuries away from the religious tradition of a stable social order organized around an unquestioning relationship to God and King (the Classical Age), to the age of social reform spurred by the rise of scientific and analytic thinking (the Enlightenment). The promise of modernity had given people more control over their social conditions, but what this meant in actuality was a different kind of social control over the people, a situation described by Foucault (1983, p. 210) as a "new economy of power."

In the modern social order, knowledge of "self," one's body and mind, was to be organized and supervised by an increasingly professionalized and disciplined social body. The social science of psychology, for example, constituted a new way of organizing, supervising, and wielding power over the individual in that "the individual's innermost thoughts were made the focus of the experts' gaze" (Popkewitz, 1991, p. 39). In the $20^{\text {th }}$-century United States, the influence of psychology was seen in how the purposes and procedures of modern schooling became inherently supervisorial. A focus on the character of the students was paralleled by a focus on the character of the teacher and her "specific attitudes of intellectual discipline and self-possession" (Popkewitz, 1991, 
p. 68). We see this focus in Dewey's (1938) prescription of the properties of inquiry-oriented reflection: through its use, he wanted teachers to achieve a "self" characterized by orderly, consecutive, appropriate, and logical thinking.

Today's postmodern writers on the role of reflection in teaching and teacher reflection value other "attitudes of intellectual discipline and selfpossession," but they nonetheless rest on the same premise of a "self" capable of "self"-management. To Kincheloe (1991), for example, it is not the intelligence of the reflection that matters, but its ethical and political nature. He wants reflection to help teachers develop "selves" committed to critical action research. The question he wants preservice teachers to ask themselves in this project of "self" formation in multicultural teacher education-i.e., "Do I unconsciously respond to the children of the dispossessed differently than I do the children of privilege?" (p. 103)—reflects a goal of educational equity.

The emancipatory ends of this question, however, do not free it from its "power effects" in the multicultural teacher education classroom. A critically reflective "self," the multicultural teacher education literature claims, is more likely to teach in culturally appropriate ways and to shift blame for school failure away from students and towards the instructional situation itself (Zeichner, 1993). Critical reflection, it is argued, enables preservice teachers to see how their views influence instruction and then ultimately how the instruction they provide, or the manner in which they provide it, may not be in the best interest of their students. "Critical self-reflection," as Ndura (2003; 2004) asserts, "becomes an essential part of the learning process."

However, the multicultural teacher education literature is full of accounts of resistance to critical reflection. Allard and Cooper (1997) explain that preservice teachers come to feel that their own voices are being drowned out by wellintentioned but over-zealous teacher educators (as cited in Wideen et al., p. 148). Zeichner (1993, p. 14) and Boyd, Boll, Brawner, and Villaume (1998, p. 68) also document this outcome by describing how their students felt critical content was forced upon them in their reflection-oriented programs. Accounts like these have led to recognition of the need to reconsider the criteria for critical reflection so that it is not confused with indoctrination (Valli, 1997).

\section{The Research Background}

I had the opportunity to explore the workings of critical reflection during the three years that I observed and interviewed teacher candidates in a required "Cultural Diversity" course at a large research university in Northern California (Richardson Bruna, 2002). I examined the experiences of 27 preservice teachers in that course and those of the one teacher educator. This article draws from the pool of ethnographic data I collected in the first year of that study with my initial cohort of 10 teacher participants. Eight of these participants were White, one African-American, and one Mexican-American. The data reported 
here comes from a series of ten 2-hour class observations, ten 90-minute interviews (one with each of the preservice teacher participants), three hour-long interviews with the teacher educator, as well as the collection of course-related documents, such as course evaluations. Here I recount an experience of one preservice teacher in the class, Yvonne, through interview data from her, some of her peers, and her instructor, Ellen.

Importantly, in my discussion of the incident that follows, I am not making the argument that White teachers cannot be racist or do not possess White privilege. I am making another argument entirely. I am suggesting that Ellen, the multicultural teacher educator, plays an important role in triggering resistance and that this resistance is then used to (re)inscribe racist and privileged identities on White teachers. This phenomenon has not been sufficiently understood by multicultural teacher education scholars, especially the role it plays in the miseducation of the White preservice teacher.

\section{(Re)Inscribing White Identity: Constructing White Resistance}

Ellen, Yvonne's instructor, is a White woman who came into sociocultural consciousness as a high school student in mid-1960's urban Northern California. As an undergraduate at UC Berkeley, Ellen traveled to Mexico many times, eventually taking up a post-graduation teaching post that enabled her to become fluent in Spanish and to have a successful 15-year career as a bilingual teacher back in California. Ellen felt very strongly that teaching was a political act. A quote that she put on the board-"If you don't take multicultural education seriously, then you are providing a racist, monocultural education. There is no neutral ground on this issue" (Lee, 1985)-highlighted the importance she placed on having preservice teachers see themselves as advocates for social change. Ellen spoke to that philosophy when asked to describe her course objective:

I would hope that the student teachers would start to rethink some of the assumptions that they've had all their lives, some beliefs that they've had about people that are different from them, some stereotypes.... I really need for them to reflect on their beliefs and assumptions, and to start looking through a different lens.

In order to accomplish this objective, Ellen believed that part of her role in the classroom was to model good teaching. "I need to do what I think they should be doing with their students, which is making students feel comfortable and allowing them to dialogue," she said. As witnessed, however, Ellen's goal of modeling good teaching did not always square with that of giving them a different lens. Her commitment to dialogue was easily trumped by an investment in her White preservice teachers as "a particular human kind" and, specifically, by her intolerance when their lenses diverged from her own. Below I offer an incident involving Yvonne as an illustration of Ellen's authoritative (re)inscription of White identity and the resistance, I argue, to which it ultimately led. 
Yvonne is a White, upper-middle class, monolingual English-speaking preservice teacher in her early twenties. She grew up in a community not far from the university, a community that she admitted was racist but, while doing so, insisted that her family did not share these racist views. Because of her perceived color-blind upbringing, it was hard for Yvonne to reconcile herself to the attention given to racial difference in the "Cultural Diversity" class. Indeed, only two weeks into the course (which met once a week), she made a conscious decision to "turn off."

Ellen began the second week's session by putting on the overhead projector a figure from the chapters the preservice teachers had been assigned and asking them to discuss its representation of the "referent ethniclass" (Spindler \& Spindler, 1990, p. 33). The figure is a grid with class status indicated on one axis and ethnicity on the other. In the center, where upper-and lowermiddle class intersect with Protestant, European non-ethnic, is a box labeled "referent ethniclass." This is bordered by the word "mainstream." Ellen asked her preservice teachers to reflect on themselves in relation to the figure. "If you're not already in the box," she wondered, "then how do you get there?"

In response to this request to reflect, Yvonne shared an anecdote. She told a story of a man who lived in her neighborhood. It is a rags-to-riches tale of his struggle with poverty and drugs and of the teacher who turned his life around. It is a tale that speaks to the meritocratic ideal, to prove her point that people can break through social barriers and get into "the box" if they work hard enough. The story concludes with Yvonne saying "It takes drive and determination to get yourself into that box; it doesn't just depend on race and socioeconomic status." Using language that captures the confrontational nature of an exchange that followed, Ellen said, in a later interview, that "Theresa jumped her shit for that."

Theresa is an African-American woman in her late thirties. She came from a working class family and lived in what became, after a period of White flight, a predominantly African-American neighborhood not far from Yvonne's. Theresa countered Yvonne's story, particularly her last comment, by citing examples of the discrimination she experienced daily. The atmosphere in the class, as a result of Yvonne's and Theresa's exchanges, became one of "fighting" and "blaming" according to other preservice teachers. What was the multicultural teacher educator's role?

Ellen recalled that her response was one of just "letting it go." Her decision not to mediate was motivated, as she later described it, by a desire to "give voice" to Theresa who, she believed, deserved institutional space to tell her story. Yvonne, on the other hand, interpreted Ellen's "giving" voice to Theresa as "taking" hers away. She saw Ellen's non-participation as evidence that Ellen was "not listening" and made a conscious decision to disengage: 
I was very open in the beginning of the discussion and after our teacher did that and she didn't listen, I kind of hunched over and was doodling in my book and I totally turned off because I figured if she didn't want to hear anything I had to say, I wasn't going to listen to anything she had to say.

Two weeks after this incident, Yvonne went to see Ellen during office hours, in her words, to ask her what the "goals" for the class were. While talking with Ellen, Yvonne made the assertion that there was reverse discrimination operating in the course. Yvonne told me:

I felt like the white people in the class were getting discriminated against purely because they were white, because of the way the discussions would go. So I went and asked [Ellen] what her goals were so that I could have a better outlook for the class, so I could know going in that she wasn't just going to get all over the white people in the class.

Yvonne has taken it upon herself to approach Ellen about how she is feeling in the "Cultural Diversity" class. Wanting to know what Ellen's goals were so she "could have a better outlook for the class" indicates that her experience in the course has become a miseducative one. Yvonne is telling Ellen quite clearly that she objects to being "a particular human kind for pedagogical intervention" ("so I could know going in that she wasn't going to get all over the white people in the class"). She is resisting the (re)inscription of her White racist identity in the cultural mismatch framework.

Ellen has an intensely negative response to Yvonne's continued resistance. Importantly, she minimizes her own role, delegitimizing Yvonne's claim that she was not being listened to. She attributes it instead directly to Yvonne and her "petty and immature" way of thinking:

It's a way of not dealing. It's an out. An easy out. I also think it is petty and immature thinking that some people never outgrow. "Well, I'm being discriminated against." "It's my turn at the tether ball," you know?

What emerges most frequently and saliently from the data is that many other White preservice teachers feared that they would say something perceived as offensive or, in this case, "petty and immature" by Ellen or their peers. The following quote shows how their decision not to speak is linked to their awareness that they have been inscribed as a "particular human kind" and that they, as this White preservice teacher says, "come from this kind of background so [are] not qualified": 
I'm not even going to open my mouth in this class because I'm not going to open myself up to someone turning around and saying, "Well, God, you come from this kind of background so you're not qualified."

With statements like this, White preservice teachers expressed a wellgrounded fear that with speaking came a risk. Yvonne's "beating," so called by her peers in their interviews, served as an example for others of what might happen when one shared a reflection of which Ellen or their peers disapproved. Simply put, they did not feel like their perspectives mattered. Final course evaluations provided them the opportunity to express this concern:

- At times I felt like my opinion did not count because of who I am.

- I think favoritism ran rampant in this class and it was extremely invalidating to many contributing students.

- As much as this class was about understanding one another and equality - there seemed to be favorites and favorite points of view.

- [The course] had a political agenda that was forced on the group by the instructor's teaching methods. Let's respect everyone's contribution.

- Be MULTIcultural [sic.] and aware of all students' right to be heard.

These comments make it quite clear that the students did not perceive reflection as a form of self-exploration, but, instead, as a form of regulation.

\section{Putting "Education" Back in Multicultural Teacher Education}

A mythology of multicultural teacher education is that White preservice teachers are best served by seeing them first and foremost as White. I believe this mythology is one of convenience: seeing them this way makes it easy for us to dismiss their challenges to the social justice agenda as evidence of White racism, rather than simply as questions that it is our job to help them answer. Taking the second perspective is a lot harder than taking the first. It means staying with your students even when you do not agree with them, helping them clarify their thinking by insisting they provide evidence and encouraging them to analyze what effect their thinking has on the world. Taking the second perspective means, in essence, actually teaching. It is part of what Grossberg (1994) calls a pedagogy of articulation and risk. Describing this model, Obidah (2000) writes:

A pedagogy of articulation and risk also seems to include the moments when teachers assert their knowledge, but with space in the assertions for students' questions, contestation, and even, resistance. (p. 1041, italics mine) 
Multicultural teacher educators know that White people evade engagement with their Whiteness as a location of racial privilege (Frankenberg, 1993 , p. 19), yet we continue to feel inconvenienced by reflections like Yvonne's and hold such reflections against her. This is because we look at our students through a cultural mismatch framework. The goal of confirming the reality of racist identities among our preservice teachers-"there you have it; I see you are indeed a 'typical' White teacher"-has misplaced the goal of affirming the possibility of their anti-racism. This is antithetical to what we know about learning. Learning does not happen by continually hammering on about what one does not know, but instead by providing opportunities for participation in a community of knowers (Lave \& Wenger, 1991). Importantly, the provision of learning opportunities takes place with the assumption that the learner can eventually become a knower. For multicultural teacher education, this would mean providing opportunities for preservice teachers not only to examine their Whiteness, but to see themselves as potential anti-racist Whites. As Howard (1999) says, the analytical approach of Whiteness-equals-oppression "will merely serve to alienate White educators rather than inspire them to become coresponsible for positive change" (p. 111).

What Howard (1999), Obidah (2000), and other multicultural teacher educators are saying (e.g., Goldstein, 2002) is that we need caring multicultural teacher education classrooms that allow and, in fact, encourage White teachers to explore their perspectives, classrooms in which these perspectives are not taken as wholesale evidence of cultural insularity, of political disengagement, or of undeniable proof of an unexamined racist self. To have this type of classroom requires multicultural teacher educators to distance themselves from the cultural mismatch approach to the education of the White preservice teacher, an approach that makes the unexamined racist self their default identity. We who work in multicultural teacher education must take responsibility for the representational processes of race itself so that simplistic binaries of "friend/enemy, oppressor/oppressed, knowledgeable/ignorant" (Duesterberg, 1999) are no longer taken for granted but interrogated as mechanisms of knowledge production. Unless we do that, we will be predisposed to hear through a negative filter everything our White preservice teachers say, to attribute an idealized immunity to our preservice teachers of color, to create divisions in our classrooms that override the tidy rhetoric about creating dialogue across difference. In essence, White teacher candidates need to be granted the right to Gordon's "complex personhood" (1997, pp. 4-5). This means seeing more in them than just a "particular human kind for pedagogical intervention" in our efforts to manufacture their dissent.

\section{Loving Subversion: Toward the Pedagogy of White Anti-Racism}

In her ethnography of White racial identity among high school students, Perry (2002) explores what she calls the "mutability and multiplicity of white identities" and argues that "contradictions not be seen as nefarious, but as 
potential inlets for nurturing antiracism" (p. 3). What was notably missing from the "Cultural Diversity" class was precisely this-an analytical focus that would allow Ellen to regard her White preservice teachers in the anti-racist light that Perry is suggesting. Because of cultural mismatch, identity was seen as a fixed object to be manipulated rather than a dynamic process to be explored. This resulted in resistance among the White preservice teachers, resistance reflecting an overwhelming and de-motivating lack of purpose.

Multicultural teacher education can, however, nurture White preservice teachers' desire to have a positive, anti-racist, White teaching identity through a critical literacy approach (Richardson Bruna, 2002; 2004; 2005; 2007). In this model, preservice teachers learn to deconstruct and reconstruct social text (including their own White identities) as a means of articulating emergent critical practice. This approach is "critical literacy" because it helps preservice teachers see the social world as a text that can, like any other, be read-dedeconstructed, then reconstructed-so that a new meaning emerges (Kelly, 1997). Preservice teachers learn to read how the meaning of difference itself is produced and reproduced in schooling, even in their own classroom practice, so that difference begins to be understood as a social process, not as an inevitable part of the social order. Importantly, for White preservice teachers, this enables an emphasis on moving toward a positive, anti-racist White teaching identity. I have come to think of such a practice as one of Loving Subversion.

As an adjective, "loving" can describe the activity of critical literacy in a community of care. In this sense, one could say that a multicultural teacher educator and his students subvert each other's thinking in a way that is loving toward one another: that is, that the work of their subversion is conducted in a loving way. As a verb, "loving" can describe the attitude of the multicultural teacher educator and his students towards the activity of critical literacy. In this sense, one could say that they love being subversive. Both senses are productive ways of thinking about what the classroom work of critical multicultural teacher education could be. The first speaks to the ethos of a classroom where every individual is thought of as having something to contribute to the group process. The second speaks to the engagement of a classroom where, through group process, every individual finds him or herself fulfilled and in a state of enjoyment. Together, these "loving" meanings hold promise for relations of power in the critical multicultural teacher education classroom.

So what does critical literacy in a Loving Subversion practice look like in a multicultural teacher education classroom? Drawing on the feminist theorizing model of Bunch (1998, pp. 16-17) and the discussion of Kirk and Okazawa-Rey (1998, pp. 7-11), I propose that the questions which constitute a critical literacy of difference in multicultural teacher education be conceived of in four clusters: description questions (those concerned with documenting how difference exists in schools and society as academic, social, political, and economic disparity); analysis questions (those concerned with exploring, from a historical and 
contemporary perspective, what educational philosophies, policies, and practices cause these disparities to exist); vision questions (those concerned with determining what are the desirable academic, social, political, and economic alternatives to these disparities), and strategy questions (those concerned with planning for professional actions that promote equitable academic, social, political, and economic outcomes). Multicultural teacher educators can use these clusters of questions to get their students to think about or "read" their thinking.

For example, when a preservice teacher, like Yvonne, tells a rags-toriches story that downplays the role of socio-cultural factors in academic and socio-economic success or failure, the multicultural teacher educator can acknowledge the contribution by using the story as an invitation for further discussion. She can point out that while meritocratic stories of overcoming-allodds do exist, what the educational research tells us about drop-out rates is very different. "Who is most at-risk for dropping-out?" she can ask, in this way getting the students to describe what disparities exist. Once the existence of disparities is established, she can next ask "How would the ideal of meritocracy explain these disproportionate drop-out rates?" This question requires the preservice teachers to analyze the effect of meritocratic thinking on the world. Since reward is based on individual talent and/or effort in a meritocratic system, this way of thinking has the effect of explaining disproportionate school failure in terms of the inadequacies of the student and his community. What does it mean in the world to say that some groups don't do well because they are stupid or lazy? It means, for instance, that smartness and motivation are purely genetic traits and it also means there must be enough jobs and equal access to those jobs for all these genetically-selected, motivated and smart people. Does this way of thinking about the world fit with what we know about the world? If it does not, then it is not an adequate theory. If it is not an adequate theory, then what purposes and whose purposes does it serve? What might be a better theory? Is a theory that accounts for how structures in our society, like schools, and practices within them, like tracking, work to withhold success from certain groups speak more accurately to what we know about the world? With questions like these, the teacher educator moves the preservice teachers to a deeper level of understanding and enhances their ability to see inequities as sociallyconstructed, not as just "the way things are."

Once preservice teachers are at this deeper level, the teacher educator can continue by encouraging them to envision alternative scenarios. She can ask, "What would we like to see happen with drop-out rates?" Would we feel better in a world where we saw that students from different groups were at equal risk of dropping out, or would we feel better in a world where drop-outs did not exist? These questions take them to the final cluster of critical literacy questions, those which prompt them to plan for what would need to happen in society, in schools, and in their practice to bring the alternative scenario into being. "What would we like to see ourselves doing for the children in our classrooms to reduce 
their risk of dropping out?" Addressing questions at this planning level is where the really critical work of multicultural teacher education as a process of professional preparation begins. And it is here where critical reflection, as a tool to help preservice teachers clarify and target instructional decisions and behavior, finds a most appropriate place in the multicultural teacher education curriculum. Reflection at the planning level channels the new knowledge created at the description, analysis, and vision levels into a plan for personal and professional practice. Reflection here is liberating and purposeful, not oppressive and purposeless. As one of my White preservice teachers remarked to me, "it's made me think clear out of my bones" (Richardson Bruna, 2005). This is the kind of deep thinking we withhold from "typical" teacher candidates like Yvonne when we are duplicitous about our use of reflection, summarily dismissing their beliefs before allowing them a chance to explore for themselves the effects of those beliefs on the teaching, learning, living world.

\section{Conclusion}

My analysis of Yvonne's conscious decision to "turn off" her instruction in the "Cultural Diversity" course counters the one told of White preservice teacher resistance in multicultural teacher education. It suggests that we are missing out on an important aspect of the White preservice teachers' experience in multicultural teacher education by understanding resistance through an individualistic rather than a socially-constructed lens. By focusing on resistance within an individualistic framework where it is regarded as an essential characteristic of White identity, we gain political advantage. We can foreground the "typical" preservice teacher's White racist identity and maintain a focus on the whiteness=oppression equation that is the enduring legacy of colonialism at home as well as abroad. By focusing on resistance within a socially-constructed, communicative framework (Abowitz, 2000), as something emerging out of interactions in the classroom, we gain pedagogical advantage. We can examine the miseducative effects of reflection, theorize about its influence on motivation in multicultural teacher education, and design alternative approaches that, by promoting the possibility of a positive anti-racist White identity, keep preservice teachers "turned on." Resistance, as Abowitz (2000) argues, "can be viewed as a productive step toward inquiry" (p. 899). Such a view on resistance must be an essential feature of our shared multicultural teacher education research and teaching agenda. Yvonne's thinking about the cultural and linguistic diversity she will certainly encounter in her classroom-whether the veil of her perceptions will be lifted or lowered more firmly in place-depends on it.

\section{Notes}

1. I am indebted to Gary Howard for this phrase. He used it in a private conversation with me at a REACH (Respecting Ethnic and Cultural Heritage) Conference in St Paul, Minnesota in 2002. 


\section{References}

Abowitz, K. K. (2000). A pragmatist revisioning of resistance theory. American Education Research Journal, 37(4), 877-907.

Allard, A., \& Cooper, M. (1997). "Too much talk, not enough action": An investigation of fourth year teacher education students' responses to issues of gender in the teacher education curriculum. Paper presented at the annual meeting of the American Education Research Association, Chicago.

American Association of Colleges of Teacher Education (1999). Teacher education pipeline IV: Schools, colleges, and departments of education enrollment by race, ethnicity, and gender: Author: Washington, DC.

Boyd, P. C., Boll, M., Brawner, L., \& Villaume, S. K. (1998). Becoming reflective professionals: An exploration of preservice teacher's [sic] struggles as they translate language and literacy theory into practice. Action in Teacher Education, 19(4), 61-75.

Bunch, C. (1998). Not by degrees: Feminist theory and education. In G. Kirk \& M. Okazawa-Rey (Eds.), Women's lives: Multicultural perspectives (pp. 14-17). Mountain View, CA: Mayfield Publishing.

Choy, S. P., Henke, R. R., Alt, M. N., Hedrick, E. A., \& Bobbitt, S. A. (1993). Schools and staffing in the United States: A statistical profile, 1990-91. Berkeley: MPR Associates.

Council of Economic Advisors for the President's Initiative on Race (1998). Changing America: Indicators of social and economic well-being by race and Hispanic origin. Washington, DC: Author.

Dewey, J. (1938). How we think. Chicago: Henry Regnery. (Originally published in 1910).

Dreyfus, H., \& Rabinow, P. (1983). Michel Foucault: Beyond structuralism and hermeneutics. Chicago: University of Chicago Press.

Duesterberg, L. M. (1999). Theorizing race in the context of learning to teach. Teachers College Record, 100(4), 751-775.

Ellison, R. (1947). The invisible man. New York: Random House.

Foucault, M. (1983). Afterword. In H. Dreyfus \& P. Rabinow (Eds.), Michel Foucault: Beyond structuralism and hermeneutics (pp. 208-226). Chicago: University of Chicago Press.

Frankenberg, R. (1993). White women, race matters: The social construction of whiteness. Minneapolis: University of Minnesota.

Gay, G., \& Howard, T. C. (2000). Multicultural teacher education for the $21^{\text {st }}$ century. Teacher Educator, 36(1), 1-16. 
Goldstein, L. S. (2002). Reclaiming caring in teaching and teacher education. New York: Peter Lang.

Gomez, M. L. (1994). Teacher education reform and prospective teachers' perspectives on teaching "other peoples"' children. Teaching and Teacher Education, 10(3), 319-334.

Gordon, A. F. (1997). Ghostly matters: Haunting and the sociological imagination. Minneapolis, MN: University of Minnesota Press.

Grossberg, L. (1994). Introduction: Bringin' it all back home - Pedagogy and cultural studies. In H. Giroux \& P. McLaren (Eds.), Between borders: Pedagogy and the politics of cultural studies (pp. 1-25). New York: Routledge.

Herman, E. S., \& Chomsky, N. (1988). Manufacturing consent: The political economy of the mass media. New York: Pantheon.

Howard, G. (1999). We can't teach what we don't know: White teachers, multiracial schools. New York: Teachers College Press.

Kelly, U. A. (1997). Schooling desire: Literacy, cultural politics, and pedagogy. New York: Routledge.

Kincheloe, J. L. (1991). Teachers as researchers: Qualitative inquiry as a path to empowerment. New York: Falmer Press.

King, J.E. (1997). "Thank you for opening our minds": On praxis, transmutation, and Black studies in teacher development. In J. E. King, E. R. Hollins, \& W. C. Hayman (Eds.), Preparing teachers for cultural diversity (pp. 156169). New York: Teachers College Press.

Kirk, G., \& Okazawa-Rey, M. (1998). Theory and theorizing: Integrative frameworks for understanding. In G. Kirk \& M. Okazawa-Rey (Eds.), Women's lives: Multicultural perspectives (pp. 7-14). Mountain View, CA: Mayfield.

Lave, J., \& Wenger, E. (1991). Situated learning: Legitimate peripheral participation. New York: Cambridge University Press.

Lee, E. (1985). Letters to Marcia: A teacher's guide to anti-racist education. Toronto: Cross-Cultural Communication Centre.

Marx, S. (2006). Revealing the invisible: Confronting passive racism in teacher education. New York: Routledge

McCarthy, C. (1993). After the canon: Knowledge and ideological representation in the multicultural discourse on curriculum reform. In C. McCarthy \& W. Crichlow (Eds.), Race, identity, and representation in education (pp. 289305). New York: Routledge.

McIntyre, A. (1997). Making meaning of whiteness: Exploring racial identity with White teachers. Albany: State University of New York. 
Ndura, E. (2003). A multicultural education instructor's reflective self-analysis: Facing the challenge of teaching and learning. Multicultural Education, 11(2), 42-45.

Ndura, E. (2004). Teachers' discoveries of their cultural realms. Untangling the web of cultural identity. Multicultural Perspectives, 6(3), 10-16.

Obidah, J. E. (2000). Mediating boundaries of race, class and professorial authority as a critical multiculturalist. Teachers College Record, 102(6), 1035-1060.

Parks, M. W. (2006). I am from a very small town: Social reconstructionism and multicultural education. Multicultural Perspectives, 8(2), 46-50.

Perry, P. (2002). Shades of white: White kids and racial identities in high school. Durham, NC: Duke University Press.

Popkewitz, T. S. (1991). A political sociology of educational reform: Power/knowledge in teaching, teacher education, and research. New York: Teachers College.

Popkewitz, T. S. (2004). The alchemy of the mathematics curriculum: Inscriptions and the fabrication of the child. American Educational Research Journal, 41(1), 3-34.

Richardson Bruna, K. (2002). Manufacturing dissent: The new economy of power relations in multicultural teacher education. Davis, CA: University of California, Davis. Unpublished doctoral dissertation.

Richardson Bruna, K. (2004). Addicted to democracy: South Park and the salutary effects of agitation (Reflections of a ranting and raving South Park junkie). Journal of Adolescent and Adult Literacy, 47(8), 692-697.

Richardson Bruna, K. (2005). "It's made me think clear out of my bones: Reading "race" and "resistance" through a critical literacy model of multicultural teacher education. Paper presented at the annual meeting of the American Educational Research Association, San Jose, CA, November 15-19.

Richardson Bruna, K. (2007). Finding new words: How I use critical literacy in my multicultural teacher education classroom. Journal of Education for Teaching, 33(1), 115-188.

Scheurich, J. (1993). Toward a White discourse on White racism. Educational Researcher, 22(8), 5-10.

Sleeter, C. E. (1994). White racism. Multicultural Education, Spring, pp. 5-8.

Spindler, G., \& Spindler, L. (1990). The American cultural dialogue and its transmission. Bristol, PA: The Falmer Press.

Thompson, A. (2003). Tiffany, friend of people of color: White investments in antiracism. Qualitative Studies in Education 16(1), 7-29.

Troyna, B., \& Williams, J. (1986). Racism, education and the state: The racialisation of education policy. Beckenham, UK: Croom Helm. 
U. S. Department of Education (2006). Overview of public elementary and secondary students, staff, schools, school districts, revenues, and expenditures. Washington, DC: National Center for Education Statistics. Retrieved August 26, 2007, from http://nces.ed.gov/pubs2007/overview04/01.asp

Valli, L. (1997). Listening to other voices: A description of teacher education in the United States. Peabody Journal of Education, 72(1), 67-88.

Wideen, M., Mayer-Smith, J., \& Moon, B. (1998). A critical analysis of the research on learning to teach: Making the case for an ecological perspective on inquiry. Review of Educational Research, 68(2), 130-178.

Zeichner, K. M. (1993). Educating teachers for cultural diversity. East Lansing: National Center for Research on Teacher Learning, Michigan State University. 